\title{
Rituals and Socialisation in the Udmurt Folk Calendar ${ }^{1}$
}

\author{
Tatiana Vladykina \\ e-mail: tgvladykina@mail.ru
}

\section{Galina Glukhova}

e-mail: galant@udm.ru

\section{Tatiana Panina}

e-mail: tipanina@mail.ru

\begin{abstract}
The article describes Udmurt folk calendar rites from the perspective of age and gender socialisation as one form of regulation of the ritual act. It shows, using particular examples, the interdependence of gender and age differences. Men played an important role in the process of prayer. However, the 'female theme' has become the quintessence of spring ceremonies, the main functions of which were fertility and production. A special role was given to older women who were not only the supervisors of ritual actions, but also the initiators of occasional rituals. They also established contact with the other world. Youth held an active position at the beginning of half-year as equivalent periods (palar) of calendar cycle - spring and autumn. Boys and girls were the main participants in the spring and summer merrymaking dances and at the autumn and winter gatherings. The main task of these rituals was the formation of pairs with the prospect of marriage. The eve of the holiday could be correlated with puberty. Children participated in appropriate games in which the basic images and characters of
\end{abstract}


the rituals are revealed. Attention is focused on the functions of the participants and the peculiarities of their behaviour.

Keywords: Udmurt folk calendar, rites and holidays, spring and summer merrymaking, winter gatherings, age and gender socialisation, men in the rite, child-bearing age of women, elderly people, youth, the characters of ritual actions, behavioural stereotypes.

\section{The Udmurt folk calendar}

The Udmurt folk calendar is a vivid example of an interaction of cultures. It preserved the old views of ordinary and sacred time as a particular manifestation of the recurring natural cycle, it preserved the evolution of these views and their influence on interethnic contact and the world religions. Milestones in the annual cycle, its structural components and the nomination of ceremonies are directly related to ethno-genetic processes in the Ural-Volga region. At the same time terminological vocabulary is locally differentiated: the northern Udmurt had the influence of Russian folk and Orthodox calendars, while the southern Udmurt and the Udmurt of the enclaves in Tatarstan and Bashkortostan had the influence of Turkic cultural traditions (Vladykina, Glukhova 2013: 115). These local variations in the calendar give the opportunity to consider the peculiarities of its formation and development, and its importance in the general system of ethnic culture.

The schedule ran according to the seasons: winter ( $t o l)$, spring (tulys), summer (guzhem), autumn (siz'yl), taken from the annual cycle (ar), which was divided into two semesters, autumn-winter and spring-summer and were considered equal and equivalent, existing in a pairs (palar six months; unpaired year).

The borders of the semesters were the days of the winter (vozhodyr/uyvozho) and summer solstices (invozhodyr/invozho), perceived as dangerous and requiring special reverence. The majority of the calendar festivals (vozho-yuon/tolsur/roshvo; 
Kuarsur/Gerber/Guzhem-yuon/Petrol) are related to these periods or are associated with the beginning and end of agricultural work (Akashka/gery potton; pörtmas'kon/siz'yl-yuon).

Great value of the autumn-winter period is seen in the coincidence of the concepts 'autumn' and 'year' (ar) (Alatyrev 1988: 98-99), although views about the new year beginning in autumn are preserved only in fragments and associated with a more archaic counting of the time, when an important calendar milestone was the beginning of the hunting season, connected to the time of the autumn sowing (Vladykina, Glukhova 2011b: 14).

The ancient tradition of considering spring as the beginning of the new year was preserved in the rites of the first thawed patch of ground (guzhdor) and the seeing-off of ice (yö-kel'an). In agricultural tradition these were united with the beginning of planting (Akashka/Akayashka), and in the Christian calendar with Easter (Byddzh'ynnal/Paska/Vel'iktem).

The division of the year into specific months is a rather recent phenomenon, nevertheless it is usual to make a division of twelve months. Their names are a synthesis of different types of time measurement according to the cycle of the sun and periods of the moon, duration of hunting, care of cattle and the rhythm of agricultural work. For a long time the main milestones of the annual ritual cycle were not correlated with the modern calendar: their confinement to specific dates is rather recent and is often linked to Christianisation. Therefore one and the same month had several names, especially in local tradition, for example March was yuzhtolez'/oshtolez'/kuakatolez'(lit: 'month of thin crust of ice over snow' / 'month of water' / 'month of [the arrival of] rooks'); April was oshtolez'/kyz'putolez'(lit: 'the month of water' / 'month of birch sap'); June was invozho /vozhtolez'/l'ektolez'(lit: 'month of invozho' / 'angry month' / 'transition month'); August was gudyrikoshkon / siz'yl/dzh'egkiz'on/vil'dzh'uktolez' (lit: 'month of passing thunder' I 
'autumn month' / 'month of planting rye' / 'month of new cereal'), etc. (Vasil'yev 1906: 346-349; Vladykina, Glukhova 2011b: 128-129).

The modern weekly cycle of the Udmurt, as in other cultures, consists of seven days. Their names reflect traces of ancient time reckoning and the influence of Christian (Russian) and Tatar cultures. Initially a quinary system built on an opposition between working days and sacred days was used. Three of weekdays were nameless, i.e. they were simply called arn'a 'day of year', '[the shortest] short period of the year', 'the nameless day', while the sacred days were connected with sacrifice: in one case the slaughter of an animal (virnunal - lit: 'blood [of thanks offering] day'), in other there was no sacrifice (kösnunal lit: 'dry day' / 'fast day'). In the modern nomination of weekdays the first name is associated with Wednesday, the second with Saturday (Vladykina, Glukhova 2011a: 39-40). (Compare in this regard a typology of the nomination of the Baltic-Finnish peoples in Vinokurova 1994: 18-19).

The perception of particular 'transition' calendar days - more often periods - from the point of view of the ordinary/profane and the sacred, every day and festive time gave rise to the common term yuondyr (lit: 'time to drink [a ritual drink]') as well as the sporadically used shyd-s'iyon [dyr] (north, lit: '[time of] eating a soup'). Therefore the Udmurt language and ritual traditions have preserved the notions of a magical connection of festive culture and ritual drinks/ritual food. Intoxicants made on the basis of bread (grain, flour, malt) such as kvas (s'ukas'), beer (sur) and home-made wine (kumyshka) became not only an attributive symbols of the holiday, but also became the basis of their local names: tolsur (lit: 'winter beer') meaning 'winter festival' ( $\approx$ Christmas); Kuarsur (lit: 'leafy beer') meaning 'summer holiday' ( $\approx$ the Trinity).

For example, northern Udmurt had common terms for the autumn youth gatherings nyl-braga (lit: 'maiden mead') meaning 'girls' holiday', and the end of the autumn field work the kolkhozbraga (lit: kolkhoz braga) meaning 'collective farm holiday'. It is 
obvious that the term braga was used instead of the previous term (apparently not without the influence of the old believers' culture): nyl sur/nylsur 'maiden beer', nyl braga 'maiden mead' both of which equate to 'autumn festival' (autumn youth gathering).

\section{Village community gender and age stratification in the system of calendar holidays}

The content of a rite gives information about features of behavioural stereotypes. Here are two examples.

The Northern Udmurt called the winter solstice vozhodyr (lit: 'transitional period', 'crossroad' / 'transition of time'; 'time of evil spirits' / 'time [of outrage] of vozho'). With the introduction of the Christian chronology and the transition to the official calendar this period was timed to Christmastide, i.e. from the $7^{\text {th }}$ to $19^{\text {th }}$ January. The name reflects how this period was identified as sacred (in direct opposition to ordinary time, as also with the Komi 'vezha 'holy'/'consecrated'/'sacred' (Lytkin 1999: 50)).

According to the archaic beliefs of the Udmurt, in the days of transitional time the spirits vozho 'come out' from the water, personified as little black and white creatures in zoomorphic and anthropomorphic shapes. Anything abnormal that happens to people at night during this period is ascribed to their tricks. To combat this, people used an elaborate system of prohibitions and amulets. They tried not to walk outside, were afraid to pass across bridges, didn't walk near abandoned houses or bathhouses at dusk and at night, especially around midnight. It was believed that vozho live in these places. People protected themselves by invoking God's name: “Oste, Inmare!”('My God!') or by using invective language. Children were told: "En pota ber uyin: vozhoos vetlo/kutozy" ('Don't go outside at night: vozho walk' / 'they will catch you'). Crying children 
were also threatened with vozho: "En börd, vozhoos s'örazy nuozy" ('Don't cry, vozho will carry you off [under the water]').

At Christmas there was a ban on certain activities: washing floors, doing laundry, going to the bathhouse, taking ash out of the furnace, rumpling linen and making malt. If doing the laundry was unavoidable, people were guided by prescriptions not to leave the washed clothes outside before going to bed, otherwise vozho will "behave outrageously", cutting the clothes and throwing dirt on them. After washing the water was poured away only in the evening and the spot covered with snow.

During these days people had to do needlework, although even so it was limited. Spinning and knitting were only permitted in the afternoon and late in the evening, doing this work in the twilight was strictly forbidden.

According to the materials of the 19th century, in the tradition of the northern Udmurt the first day of Christmas was called 'the treat [lit: soup] of vozho' (vozho-shyd). The highlight of the day was sharing a meal in the village community hall (shyd-s'iyon), under the leadership of the chief priest (zek pop). Appealing to the original mother vozho (Vozho-mumy) he requested that she not harm the people during two 'terrible'/'transitional' weeks so that the spirit 'would go without anger into the water on January 6 [Church calendar], and the next year would contribute to the good crops" (Pervukhin 1888 (2): 130).

On the night of Epiphany younger people 'conjured' the spirits (vozho-kel'an) from their terrestrial habitat going from bathhouse to bathhouse with songs, drew a circle with burnt wood inside and 'listened to destiny', appealing to the invisible beings with the demand that they get out, "Pote tatys?" ('Get out from here!).

One peculiarity of the winter transition period among the northern Udmurt was a woman's holiday, the day after Epiphany. Women chose an old man as the master of the rite and under his leadership went from house to house with songs and dances. This feast ended the winter cycle, initiating the spring period. 
'Meeting' and 'seeing-off' of vozho included the following components: gatherings, divination, disguise.

Gatherings were the main form of entertainment and took place in the bathhouse or in a house specially purchased for the occasion (pukon korka). For boys and girls, gatherings were an opportunity to get acquainted, to find a groom or a bride. Participants competed in wit, intelligence, storytelling ability, life stories, making puzzles, singing. Everything that was told or sung at these gatherings was called vozho-mad' 'stories/tales/songs of [the time of] vozho'. There were special games played only during this period. The main idea was projected onto the producing power of man and nature ('to shoot grouse', 'bundles') and communication with the ancestors ('hide and seek', 'butterfly').

This time was also considered favourable for divination (tunatskon): the girls wanted to know the future in order 'to see' their betrothed. The whole Christmas period was considered favourable for the predictions, but especially attractive and popular was the night from $13^{\text {th }}$ to $14^{\text {th }}$ January, vozholen l'ek dyryz (lit: 'the most evil/powerful time for the vozho'). Old people also conjectured on this night. They wanted to know about the coming year, the harvest and whether or not the livestock would produce good offspring.

All members of the village community from young to old were involved in winter disguise (vozhoyas'kon, from vozhoyas'kyny 'to dress up, to camouflage', lit: 'to be like vozho / to turn into vozho'; vozhoyas'kysa vetlyny, lit: 'to walk [in the shape] of vozho'). Children dressed in the afternoon, and adults and youth in the late evening. People gathered in one house, usually at the end of the village, and there changed their dress. It was believed that the mummers should be an odd number. A person was permitted to participate in disguise not more than three times. There were masks made from birch (tuy bam) and leather (suron bam); a mask of 'laughing death' with teeth cut from a raw potato; a face smeared with soot (suam bam) or covered with white canvas (later tulle, 
gauze or a white handkerchief) is considered an archaic Christmas mask. It is obligatory to have zoomorphic (bear, horse, cow) and ornithomorphic masks (magpie, goose). The anthropomorphic masks are 'the old man' and the 'old woman', 'the Mari', 'soldier', 'beggar', 'hunchback', 'pregnant'. One of the most common types of disguise was the travesty, in which a man wore homespun female dress (shortderem) or linen skirt (dera yubka); he then tied a cloth on his head and put a cradle made of homespun linen (nyp"yet) or bast (muchko) on his back. In return women wore men's outerwear (now a jacket), trousers and hat, and were girded with an embroidered towel. They could make some sounds or sing songs with disguised voices only on the street. They dragged the people they met into the snow. At the entrance to the house they signalled their arrival with noise and a loud thud, but the house was entered silently. They banged with sticks on the floor in the shed, danced in a circle to the accompaniment of the oven dampers, rollers for ironing, washing boards. The hosts tried to recognise the mummers by attempting to remove their masks, and by pinching and tickling them to make them speak. Those who were not recognised took of their masks at the last moment, after which they were treated to beer, specially prepared for this holiday, as well as cakes, bread and even flour. After returning home they fed the cattle with this food, believing that the disguise contributed to the animals producing offspring and that it brought good luck in other affairs, for example promoting harvests of hemp, flax and cabbage. Therefore, despite the fact that the mummers came deep in the night, gates and doors were open and they were welcomed in every house.

Many ritual components of the Christmas period (prohibitions, charms, divinations, disguise, and gatherings with the obligatory needlework) were preserved during the years of the Soviet Union, despite antireligious propaganda. Even in the 1960s and 1970s, elderly people believed in the magical function of the rituals. This is evidenced by reports of informants, who stated that in some villages older women, believing in the magical power of disguise, believed 
also that it was necessary to visit the neighbours at least once in the guise of a mummer over the Christmas period. In addition, the archaic traditional masks disappeared and ethnic costume or its details became attributes of the disguise. The younger people took a minor part in the events, but the primordial function of the ritual was lost: disguise became just fun. This was caused by widespread tradition of New Year's masquerades in kindergartens, schools, clubs, and urban culture houses. Attempts to revive the

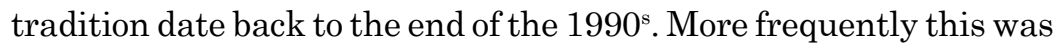
initiated by young people, moreover in the city, and this led to the inclusion of elements that were uncharacteristic of Udmurt ritual, for example loud singing, dancing, and dialogue with the hosts.

The Christmas cycle of the northern Udmurt included the obligatory ritual component of seeing off the spirits that came from the underworld during this period. The ceremony was timed to the Epiphany (yö vylyn sylon lit: 'standing on ice'; kres'en'n'al kreshen'n'a). People gathered in a special hut that was bought for a small fee by the youngsters after the New Year. The evening before the festival the young people went from house to house, inviting guests with the words: "Come to the feast of vozho", lit: "Come to drink vozho home-brewed beer' ("Vozho-braga yuyny lykte"). Everything was done beforehand: the products were collected, drinks were prepared, meals were cooked. The visiting continued until late into the night. Then gatherings young people began in the bathhouses. First having outlined themselves with a charred piece of wood they 'listened to destiny', and then conjured 'spirits'/"water sprites'. Compusory matchmaking was the order of this day.

In the early morning the girls stoked the bathhouse and the men having taken axes, sticks or twigs, went to the river under the leadership of the priest and pounded on the ice and screamed, conjuring vozho. Then they washed in the bathhouse and went to Church to attend the ceremony of consecration of water. After returning home they cooked porridge with poultry (goose or duck), and the priest's assistants (pokchi pop) went around the houses 
praying using the established rules, completing the Christmas cycle vozhodyr/vozhovyl.

A striking example of gender and age stratification of society in the ritual is presented by Shrovetide, which held a special position in the system of calendar holidays because it marked the transition from winter to spring. It was celebrated in late February or early March, necessarily taking into account the transition of the moon from the last quarter to the new moon. This is reflected in the proverb "Washing dishes should be seen by both the old and young moons" (Tus'ty-pun'y mis'kemez tolez'vuzhez no, vyl'ez no med addzh'oz), and in naming March 'the month of washing/cleansing dishes' (tus'typun'y mis'kon tolez) in one of the local variants, a meaning that stems from the tradition of cleansing before Lent. Obviously, these symbolic expressions are evidence of the influence of folk Christianity, which absorbed archaic ideas about the changing seasons and corresponding behavioural stereotypes as they relate to the etiquette norms of Orthodoxy. The ritual in this context is manifested differently in different local variants and gives the opportunity to speak about inter-ethnic relations in the Ural and Volga region.

Unlike the Russian tradition, Shrovetide in the Udmurt tradition began on Thursday, 'Udmurt Sunday', and ended on Sunday in the southern part of Udmurtia and Monday, marked as a 'day of horseradish' (kren/kirennunal) in northern districts. The height of fun was on 'Russian Sunday' (dzh'ucharn'a). Horses were dressed up for this day with bells, the head towels of married women (chalma), ribbons (chuk), etc. Tassels of coloured wool were plaited into their manes and they were covered with homespun blankets and sheepskin coats; sometimes the horses were even dressed in trousers. People rode on pillows in carts, went into the yards and drove around in circles. Sometimes a lit iron stove was put in a sled harnessed to people who danced and dragged the sled through the village. The northern Udmurt had a tradition of burning ordinary straw or cow dung on the street or in front of their gates over which 
people rode horses or pulled sledged. Torches were lit as another kind of fire on this day.

An important component of Shrovetide, as in other calendar holidays, was ritual visits to relatives and neighbours' houses (is'kavyn-böl'ak), where the status of older members of the community was especially emphasised. Festivals/entertainments were the prerogative of the young people. Southern Udmurts had the culmination of Shrovetide merriment on Sunday, which was perceived as a day of seeing off. The whole village participated in this action. The northern Udmurt did this from noon until midnight with only older women leading the ceremony and unmarried young people necessarily presented in their 'suits'. The old woman wore long six-wedged (sometimes more) red dresses (shortderem) and went from house to house, feasting and singing a melody of guesting (yuon-golos). The fun was accompanied with dance songs (purultem mad'), the texts of which were quite frivolous and were perceived as unsavoury outside of the ritual.

The seeing off continued the next day after noon, although here the main role was played only by women of childbearing age.

Anthropomorphising the holiday led to the production of a special dummy for the mumming of participants. The attributive symbols of Shrovetide for the northern Udmurt are straw and the horseradish root. There is evidence of making Shrovetide ritual dummies in the shape of an old man or old woman in the southern part of Udmurtia. But because in the Udmurt language there is no grammatical indicator of gender, descriptions of the fact in different local traditions do not always identify the female or male appearance of the dummy.

Most often the details indicate a female image, for example a woman's dress, apron or shawl are mentioned. Sometimes the doll gets a female name (Kabysta-apay 'auntie Cabbage', i.e. aunt Vulva). The Udmurt of Bashkiria had 'male' dummy that wore a shirt (the Udmurt word derem is translated as 'woman's dress' 
or 'shirt') and trousers stuffed with straw. But taking into account the details of the Udmurt women's costume, with its compulsory trousers, and the leading of the dummy through the village (two men 'hug' it from either side, its legs are tied to their legs, or they put dummy's trouser leg in the tops of theirs boots, then they 'lay with' the dummy in the snow beyond the village), the perception of the dummy as a woman is justified.

Northern Udmurt youth participated in the ceremony on Monday morning (kren/kiren-nunal lit: 'day of horseradish'). They harnessed the horse to the sleigh and rode through the streets. Used brooms were hung on the ends of a shaft and a big bell was attached to the collar instead of small bells. They rode through the streets in silence, without singing, laughter or music. Having passed through the village several times, they went out of the village, threw away their brooms and returned home. In the afternoon the holiday was continued by women of childbearing age who chose an old man to go with them from house to house gathering all the women to celebrate. He wore a cylindrical birch bark cap with sewn multi-coloured patches on his head. Another attribute was a long staff brought especially from the forest and prepared for the event. His wife tied the patches of cloth (deremsep) to the stick and a pouch (tamakpuyy) or headkerchief (kyshet).

The same gifts were tied around every house. In multiple villages there was the custom for women to choose two young men who, allegedly, had to protect them from attacks armed with bundles of sticks. The women took a drink and a few roots of horseradish with them when visiting the houses. They treated the men to mead or beer and gave a horseradish root as a titbit, saying: "This is all that remained of Shrovetide" (Glukhova 1997: 45-47; Vladykina, Glukhova 2009: 223-226). The prevalence of erotic symbolism (the abundance of phallic symbols as indication of productive capacity) in folklore texts and the playing space of calendar festivals (especially at Shrovetide) is also emphasised by researchers of the Slavic tradition (Agapkina 2002: 169-202). 
According to the examples, the originators of cults were mainly men (vorgoron, piosmurt), the priests (vös'as') who conducted the prayers were also men. Their role was especially significant in the spring and summer rituals that marked the completion of spring field work or on the occasion of the new harvest (yu-vös) or village prayers (meren-vös', el'en-vös'). Only men prayed in the holy groves (Lud/Keremet), the reason for which researchers see in the Muslim influence (Vladykin 1994: 202; Minniyakhmetova 2009: 16-20).

Men took responsibility for the prayer procedures as a main component of the calendar festival; nevertheless, other stages of the ceremonial complex are associated with the special status of women (kyshnomurt/kyshno/ nylkyshnokalyk lit: 'woman'/'wife' / 'female people'). And not only as a hostess who has guests during the ceremonies, but also as a special character in ritual scenarios aiming at the magic of the production: the woman's childbearing potential was used in the calendar rituals in order to enhance the growing abilities of the earth. Women also assumed a key function in childbirth and the health of family (Shutova 2009: 10), in funeral sacrifices for parents after marriage (atas-viro, the southern Udmurt custom of slaughtering a rooster if there was trouble in the new family (Vladykina, Glukhova 2011b: 19). (On the social roles and behavioural stereotypes of women in Russian traditional culture see Adon'yeva 1998: 26-28; on women's participation in ritual actions throughout the year in Slavic and Russian cultures see Kabakova 1999: 205-208; Madlevskaya 2005: 25-26; and on parallels in Vyatka see Trushkova 2009).

The participation of young people in the rituals was of great importance and age was always emphasised in the calendar cycle. For example, boys and young married men participated in spring rites of conjuring (uray-vös'lit: 'a noisy prayer', shaytan-ul'l'an lit: 'conjuring of devil/satan'), combined with the rituals of Holy Thursday in modern traditions. The young people played a major role in conjuring spirits at Christmas, as described above. At Easter, girls of marriageable age participated in the ritual of collecting food for 
prayers, making a round of the whole village. They were the main participants in the ritual round dances among the ripening grains or in the meadow during haymaking. Only young adults could attend games (shudon/shudon'n'i) and gatherings (dzhyt-pukon/ pukon'n'i) (see below). Generally, the game was perceived as one of the components of the calendar cycle and was strictly regulated by age in all cultures. Indoor games prevailed at gatherings of young people in the autumn and winter period, and round dances and other games in the spring and summer (from Easter to Trinity).

The main theme of both was matrimonial and was realised at different levels: imaginative, efficient, subject. The actional and verbal components of many games and round dances were aimed at forming couples and showing feelings in the presence of spectators. The main motive of the games was the idea of young people at a transitional age and status and their readiness for marriage (Bernstein 1988; Dolganova and others 1995; Morozov 1998).

Children at ceremonies participate primarily as observers. Some periods of the calendar emphasise the pubertal period for girls, for example the southern Udmurt collection of patches (chuk/ chacha-kuran) on Holy Thursday to sew into talismanic dolls (see on this matter the customs of the Besserman living locally with the northern Udmurt, Popova 2004: 80-81) or clothes for doll 'wedding' dances in the field (shyr-s'uan lit: 'mouse wedding' / 'wedding of mouse', where the image of the mouse is a metaphorical substitute for the penis or vulva).

\section{Women's rites in the calendar}

Highlighting the feminine theme in the calendar, it is necessary to keep in mind, first of all, the function of rituals which were aimed at the magical stimulation of the productive forces of nature. The use of women's fertility was one possible way to accomplish the task. Analysis of rituals and their content gives an opportunity to 
see that there are not separate 'female' rituals, they come generally within the festivities of the holidays. A female theme runs through all the rites of the spring summer cycle, in the period of flowering and fruiting. Moreover, the presence of women of childbearing age is prescribed both in direct participation and in attributive symbols. First of all one of the symbols is the married woman's head towel (chalma), in addition to which are a headband (yyrkerttet) and a shawl (s'ulyk). The woman's hair braided in two braids and wrapped around the head was hidden under the chalma. In wedding songs the woman's headdress is the antithesis of the small cap worn by maidens (tak"ya), symbolising girlhood. Therefore the chalma was perceived as the main symbol of parting with girlhood and gaining the status of married woman. Usually women took these towels as gifts to the family shrine (baddzh'ym / buddzh'ym kuala), or to the places of prayer in order to hang them on tree branches as a symbolic fence for the sacred space. In calendar situations, head towels were used as gifts, for example they were given to the winners of races organised at Trinity (Gershyd/Troycha/Trochin').

In northern and central districts of Udmurtia the summer holiday (Gerber lit: 'after the plough'; Gerbernunal/Gerberprazdn'ik) ended the spring-summer half of the year. It was celebrated in the last days of the summer solstice, although in the modern calendar it has become strictly linked to the 12 July. It is believed that this is the 'last feast of earth'. To this day all the spring work on the soil in which a plough was used finished on this day.

The names Guzhem-yuon ('summer feast'), Petrol (Rus. Petrov/ Petrov day), Kuarsur (lit: 'leafy beer' / 'holiday of leaves/greenery') are also known. The sun "was turning" towards autumn already and one 'unpaired' year was finishing. People finished their festive meal before noon. After dinner everyone went haymaking and, according to custom, performed the ritual of young women's bathing (s'altym). This period was also considered auspicious for weddings: "Get married this day - you will be happy" ("Ta nunale, pe, byz'id ke, shudo luod"). 
In the north of Udmurtia festively dressed singing women walked through a rye field, providing it with protection and fertility (Gerber lud orchyny lit: 'to walk through [the holiday of] Gerber'). This was one of the substitute rituals that are famous among other nations (Agapkina 2009: 361).

The symbolism of the female presence in the calendar is also formed by spinning - a purely feminine occupation that is closely related to ideas about fate. Attributes related to spinning (the spinning wheel, yarn, etc.) not only become individual symbols of calendar celebrations, but also form the basis of naming calendar rites and its components. For example during Shrovetide the Transvyatka Udmurt (who live in the territory of today's Republic of Tatarstan) had the custom of collecting village gifts on the removable top of a distaff belonging to a young woman who had married in the current year (kubochuk-kuran, from kubochuk kurany lit: 'to ask for spinning victim').

During visiting from house to house, the hostess donated patches, ribbons, towels, while young women donated head towel chalma. The distaff as a symbolic attribute of the holiday was apparently ambivalent semantically, as was the personification of the holiday, the Shrovetide dummy, with its male and female attributes. If the distaff as a whole, especially its lower part, was associated with the feminine, the removable top of it was thought of as male. In this regard, the leading role played by boys and young men in the ritual becomes clear.

The northern Udmurt added to the ritual the process of washing reels of yarn that had been spun during the winter (short-mis'kon) (Pervukhin 1888 (2): 110-111). The yarn was washed in turn at all the farms. A hole was cut in the river and neighbours were invited to help. On the appointed day, the women gathered early in the morning, harnessed the horse in a good harness with bells, rode in the sleigh on the hanks and went to the river with laughter and jokes. Here the elder woman poured the wine, prayed and threw a piece of bread into the hole. After that everyone began merrily to 
wash the reels of yarn. Young married women were jokingly forced to untangle knots as it was said that the house spirit (korkamurt) had tangled them as punishment for defiling the marriage bed. During this time people tried to splash them (equivalent to the southern Udmurt bathing of the young married women, s'altym, on the first day of haymaking). Young women had to treat guests with wine. After work they returned home with songs, dressed in festive clothes, and arranged a feast.

Upon completion of the washing, a common village holiday (short-tuy lit: 'yarn holiday') was arranged that included all farms. Food was prepared in the morning and Lenten porridge was cooked because the holiday fell on the days of Lent. Village priests went from house to house, sanctifying the food. Then the women went with a distaff from house to house, showing a desire to spin and a ritual meal was held in each house. Women's aid during the days of Lent marked the end of spinning.

'Spinning aid' (cherson-veme) is a commemorative rite inscribed in the calendar cycle of the Udmurt living in Kizner district, one of central districts of Udmurtia. A year after the death of an elderly woman, before the Festival of the Holy Name of the Virgin Mary, old women from the whole village come to her relatives' house and span for the whole evening. The essence of the rite was not so much to help the family, as evidenced by the name of the rite, but in the symbolism of spinning, indicating in this situation, the end of human life: death cut the thread of fate (Vladykina 2013: 37).

The ritual situations in which women of childbearing age were replaced by elder women should be considered separately. The latter were mainly involved in situations of alleged contact with the spirit world, i.e. seeing off the holiday outside the living space, 'seeing off' of funeral food into the boundary places. Only the elder women were allowed to use foul language: speaking or singing obscene expressions and songs was usually their prerogative.

The southern Udmurts celebrated the holiday of the spring meeting, which was joined with the Christian Easter, over three 
days including the Great Day (Buddzh'ymnunal/Byddzh'ynnal/ Paskha), 'holiday'/'day of going into the ploughed field'/'holiday of the plough' (Akashka), the seeing off [holiday] of Akashka (Akashka - kel'an / ul'l'an). On the last day, older community members, mainly women, went from house to house, following the river, singing a ritual chant at every house. Mandatory attributes were willow twigs that substituted 'horses' for the participants of the ceremony. 'Having saddled up' their 'horses' the women saw off the festival to the lower edge of the village.

During the week before Easter the eastern Udmurt (in the territory of the modern Republic of Bashkortostan) had a ritual in which older women conjured spirits away (verva-kis'ton lit: 'willow commemoration'). The old women went from house to house, visiting only the oldest people. They went down the street to the lower edge of the village, hitting the gates with pussy willow whips and bust baskets saying "pussy willow has come!" Near the river people jumped over the bust baskets and threw them across the river.

Until recently the rite of oshorok had also been preserved in the eastern Udmurt tradition. On the second day after the spring commemoration, or the fourth day of Easter, old women dressed in rags, wore inside-out coats and smeared their faces with soot. They took a stick in hand and tied a carrot or turnip to their belt, symbolising male genitalia. Sometimes these phalluses were carved from wood. Shouting "Neigh neigh" and jumping, they chased young guys, drag them along the floor, poking them with sticks or carrots. The same thing was done with young married women.

The old women tried to strip the men they met naked, imitating violence. They "neighed like horses", sang obscene songs and explained the purpose of their actions ("Kidys viyatis'kom, kidys!" 'We scatter seeds' (lit: 'forced to flow, seeds'). According to belief, the ritual helped keep the village free of disease and favoured the reproduction of livestock and the growth of plants. Today it is definitely perceived as shameful entertainment (viz'tem 
shuldyr"yas"kon) because the semantics of the ritual position it as a way of stimulating the production forces of man, meaning that nature has already been lost (Minniyakhmetova 2000: 31-32; Vladykina, Glukhova 2011b: 103-104).

The old women secretly regulated the structure of the rites as the original guarantors of the correctness of events, transmitting knowledge to the younger people (n'erge-utis' lit: 'custom keeper'). Most often they were the initiators of rites, especially occasional rites such as the ritual of summoning rain during drought (zorkuron) (Khristolyubova 1995: 153-156; Minniyakhmetova 2000: 47-49; Vladykina, Glukhova 2011a: 76). Occasional rain rituals had compulsory parallels in the calendar cycle, the functional orientation of which was hidden under the temporal and cultural layers. These included the rites of seeing-off, funeral rites and the 'wedding' of insects (caterpillars, bugs) (kiby-ul'l'an; numyr /urbokel'an; urbo-s'uan), all of which were characterised by elements of disguise and were confined mainly to rites of expulsion in the period between Holy Thursday and the summer solstice. The initiators of these rites were also older women (Vladykina, Glukhova 2011b: $96,136)$.

The role of these older women increased in situations when the ritual purity of women was emphasised (see Kabakova 1999: 208). For example, a somersault or rolling on the ground was perceived as sexual contact with the earth during its revival at the time of the first thunder or during the spring and summer ceremonies. The old woman rolled down hills in the ritual of the appearance of the first thawed patch of ground (guzhdor), and some old women rolled down a hill in rites associated with the production of crops. The mythological background of these actions is often disguised as more normal actions, for example rolling on the ground because of backache caused by the harvest. The logic of such actions is conditioned by the perception of summersaulting as a sexual act during which a man can give life-giving power to the land, and receive it in return. 


\section{Maiden holidays}

In traditional Udmurt culture maiden holidays are mainly associated with the autumn cycle, particularly with the initial stage of young people's gathering period. For these events, young people specifically bought a house or, with the consent of the owners, held them in a new but uninhabited house.

Upon completion of harvest, the northern Udmurt celebrated the nyl braga (lit: 'maiden mead') holiday. The ceremony lasted a day, although the planning started long before. The preparation included discussion of the day and place, the collection of food (flour, malt) for the preparation of ritual beverages (beer, mead), informing young people in the neighbouring villages (verbal or written), deciding the number of attendees as well as choosing clothing (which was supposed to be similar).

On the scheduled day, the girls gathered in one house to meet people. The newcomers were seated at the table and brought only tea. At this time, a specially selected 'newly married couple' went from house to house singing, a musical instrument in hand. They summoned boys to the feast, whom they greeted with questions about how they had arrived and whether they had lost anyone on the way. They sang the song "Where Did You Come from..." ("Kytys'en ti lyktidy...") as a greeting. People sat at the table in the same clothes, with girls in white embroidered blouses and black skirts. After a ritual meal, everyone got up from the table, except the 'couple'.

The girls cleared away the meal, folded the tablecloth and put it over the heads of the young couple. Only afterwards could the boy and the girl get up from the table. The merrymaking began, during which boys and girls continued to get acquainted. At midnight, the girls dressed in colourful dresses that were the mandatory for the situation. Then the fun resumed and continued until dawn. Toward morning, the girls once again dressed, but so that the boy could not find his chosen girl they wore someone else's clothes, covered 
their faces with headkerchiefs. The girls lined up in a row, and the boys were supposed to find their favourite girl. Those who tried to leave the party secretly (single girls or couples), had water thrown on them or were smeared with soot. In the afternoon the guests started to go home.

One of the highlights of the ritual was dressing up. The meaning of this lies, apparently, in views about the transition of girls to a different status (byde vuem, marriageable girl / fiancée). The time of changing clothes (midnight, i.e. the end/beginning of the day) also reinforces the symbolism of the action (compare: the bride changes clothes on the second day of the wedding). The disguising of the girls (wearing someone else's clothes, obscuring the face) goes beyond just being a game. It is one of the ways of depersonalising the girls as future brides, as people of liminal status related to beliefs about the supernatural world of the afterlife (compare: the substitution of the bride with her friend or an old lady in the Udmurt wedding ceremony).

More complicated in terms of semantics are these actions of throwing water over the girls and smearing their faces with soot. Since the ceremony is reconstructed from later records, the explanation of not allowing the girls to run away from celebration is definitely not enough. Apparently, all the girls should have received both treatments by the end of the ceremony. Its main point was to play out a situation of temporary death and rebirth, marked by soot and water (compare: the ritual of pouring water over the bride at a wedding (ken-pylaton) and the bathing of young woman on the first day of haymaking; also the rite of washing hanks of yarn).

A local variant of the kushman-s'uan autumn maiden feast (lit: 'radish wedding' / 'the feast of the radish'), timed to the Festival of the Holy Name of the Virgin Mary, is recorded in central Udmurtia. Girls 10-15 years old participated. The most important attribute of the participants was a hat (often the same one for all participants). It had a wire frame with a piece of swede in the middle, decorated with branches, with paper flowers and trimmed at the edges with fringe 
and ribbons. In appearance and construction it was very similar to the dev'ya krasota (lit: 'maiden beauty') of northern Russians and Slavic kvitka (Vladykina 2006: 53).

The hat was put on over a shawl and fastened under the chin. The dress was complemented with beads and a necklace. In this attire the girls went from house to house accompanied by the boys. Moreover the boys entered the house first, asking permission of the owners to come in. The hostess greeted the girls by teasing them, inviting them to dance. Girls danced and sang songs to a wedding tune. Reproaching songs were also sung, making fun of the boys from neighbouring villages. After that, the feast began. As well as baked goods, pickled beets were put on the table. Visiting houses, the girls showed themselves as future brides (Dolganova, Morozov, Minasenko 1995: 39-40).

The western districts of the Udmurt Republic celebrate a young persons' rite called siz'yl pörtmas'kon ('autumn disguise'). When it was celebrated is not clear, although modern versions are most often associated with dates related to the Christian calendar: the Festival of the Holy Name of the Virgin Mary, i.e. October 14 (1 October by the old calendar), the day of Our Lady of Kazan, i.e. November 4 (22 October by the church calendar).

On the eve of the festival, the girls made special hats of straw, decorated them with goose or rooster feathers, pieces of cloth, coloured paper. The hats were not made by all participants, one hat was made for each group of three or four people. There were about five or six groups, depending on the number of young people in the village. But everyone participated in the procession without dividing into groups. The celebration lasted only one night: the ceremony began late in the afternoon and lasted until morning. The hats were given to 'supervisors' chosen from among the boys, who kept them until the next season. The owners of each house set the table when the guests arrived. Traditionally, the route began at the end of the village. Visiting of each house consisted of several stages that have their own songs. The participants announced their 
arrival by singing and asked permission to enter the house, called the host matchmaker. A request to serve wine was allegorically expressed in the song formula 'to let the blood of a six-year-old/ forty-year-old bull' (Vladykina 2012). The obligatory motifs of the songs were arrival from far away by river (the Kama, the Kil'mez'), and the assimilation of girls and boys by migratory birds (geese and cranes). During the feast the songs performed generally contained erotic content. Their images were allegorical, and sometimes undisguised and demonstrative. This manifested itself particularly clearly in the dance songs. Leaving, the participants sang about their desire to visit another house, thanked the hosts and said goodbye to them until next year.

'Marriage' symbols correspond to the magic function of the ritual action - the rebirth of productive forces of the earth. It is necessary to consider the peculiarity of the perception of autumn as the beginning of the year, when understanding the annual cycle as two halves of equal length. Singing frivolous songs was a kind of test for understanding metaphors, demonstrative use of language about the relations between the sexes was explained by the removal of the taboo on verbal limitations in everyday life. An appeal to the wedding symbolism is natural for premarital youngster's games.

Typological correspondences of wedding and calendar rituals, caused by their transitivity, are found in other rituals performed by young people. For example, the central Udmurt had a ritual called pukis' kuno (lit: 'the sitting guest [for a long time]') (Vereshchagin 1996: 109). With the beginning of the autumn gatherings, girls of marriageable age were invited to relatives in neighbouring or distant villages, where they lived for about $2-3$ weeks, helping with the housework, mainly spinning. Both the guests and the hosts had certain expenses: the host ordered a spinning wheel (kubo) and gave money to the girl, and the girl gave wine and towels. This residency was a kind of bride-show because girls participated in the young people's gatherings. 
In the western districts of Udmurtia a separate kind of autumn girls' gatherings (siz'yl [kualan] pukyny lit: 'to sit [in kuala] in autumn') had been recorded. Adult girls gathered in someone's family kuala (family sanctuary, optionally used as a summer kitchen) sewing late at night. According to custom, before this they stole roots and baskets of sunflowers from gardens. They kindled a fire in the kuala and cooked and ate vegetables. Boys were not allowed to attend the ceremony (Churakova 1999: 15).

Girl's gatherings called pukon-taban' (lit: 'sitting flatbread') (Vereshchagin 1996: 109-110) and pukon-korka (lit: 'house for gatherings') were held in a new unoccupied house in autumn and lasted for a whole week. Young married men and women could participate. Women span and knitted, men braided sandals and played cards. At the end of the week, on Saturday, the participants brought flour and made dough. Closer to the night people went home, formed couples remained in the house. The girls made pancakes (taban') for the boys. The pairs that spent the night together were considered married.

In the morning, the girls' mothers came and made pancakes with holes and gave them to the couples. The erotic symbolism can be clearly seen in these pancakes, which symbolised deflowering as the physiological act of turning a girl into a woman. The fact that the mothers baked cakes tells about their admission of the new status of their daughters. (On the presence of attributes with a hole and metaphoric assimilation to women's genitals in a wedding ceremony of other peoples see: Tolstaya 1996: 192-206). During the feast, comic songs were sung, a characteristic of the second day of the wedding. In general, the situation imitated the wedding feast.

Eastern Udmurts had young people's autumn gatherings, called aulak/aullak/allak korka (lit: 'secret/silent house'). The participants gathered in the house of those whose parents went away. Sometimes a house for the rite was bought from lonely people. The girls brought handcraft with them. The peculiarity of the rite is a ritual meal with chicken meat. There is no information on special 
manipulations with the cooked chicken but the circumstances of the situation are explained: the chicken was brought by boys, moreover it was a stolen chicken; windows were closed, so that "nobody could see". The nomination of the ceremony is mediate, apparently, not so much by the situation of communication separate from adults, but the fact of ritual theft.

Poultry as a ritual dish in Udmurt traditional culture is associated mostly only with funeral rites. Cooking of chicken in a young people's rite can be explained by the symbolic views on girls as a birds (compare the images of female grouse, hens, pigeons, ducks in the Udmurt wedding songs). Images of migratory birds are replaced by domesticated, where the hen represents the bird in general (Vladykina 2006: 56-57). (On the analogy of the metaphorical substitutions of the image of the bride in wedding laments of the Karelian, see: Stepanova 1985: 76-77; compare also the ambiguity of the semantics of the chicken in autumn agricultural rites and marriage and erotic symbolism in the Russian tradition (Bushkevich 2004: 62-63)). The joint meal was obviously a symbolic action that binds the love of the couple and their communication. A proverb of the Bashkiria Udmurts "Aulak korkan nyl muso" ("The girls are nice in the house of aulak/during the ceremony of aulak") indirectly confirms this opinion.

In the eastern Udmurt tradition, there were the autumnwinter gatherings nardugan in a new, not yet inhabited house. Thiq name is common among all the peoples of the Volga region, The Tatar and Bashkir have nardugan, the Chuvash nartugan, nartavan, the Mordva-Erzya nartava, the Mordva-Moksha nardvan. The components of the rite, as in other traditions, were disguise, divination, dance and games (Munkácsi 1952: 31-33). One of the characteristic features of the nardugan was a game that involved boys 'rolling' girls on the sleeping benches. In the course of time, the permissiveness of the ritual situation, usual for archaic consciousness, following the logic of mythological thinking, conflicted with the ethical and religious norms of society. The 
merry and riotous pastimes of young people began to be perceived negatively, which explains the revaluation of the ceremony and adjustments not only in the semantics of the term (the Tatars called the rite of nardugan, shaytan tuyy, 'the devil's wedding' and the Chuvash shuyttan vayi, 'devil's game'), but also to the structure of the rite. Nardugan was 'played' not in a new, but in an abandoned house. Subsequently the rite was rejected by the tradition. Perhaps one of the reasons was the attitude to the festival as though it was simply revelry. In the tradition of the eastern Udmurt, the expression nardugan karyny 'to do nardugan' and nardugan karysa 'as during nardugan' mean noisy, ugly, indecent behaviour (Nuriyeva 1999: 107).

According to examples, maiden festivals had a multi-functional orientation. Their main idea was to show off the majority of the girls and to form future married couples. These festivals were timed to the beginning of the gatherings, i.e. to the beginning of autumn because this was considered the beginning of the new calendar and mating cycles.

The participation of girls in these ceremonies was a kind of initiation, only then were they allowed to go to gatherings (pukny vetlon/munchoyn-pukon / dzhyt pukynny lit: 'go to gatherings' / 'sit in bathhouses' / 'evening meetings') that were a sustainable form of young people's meetings.

\section{Women's rites and maiden holidays in the Udmurt understanding of time}

Women's rites and maiden holidays, structured by calendar, draw attention to the transitional states of the human body and nature. Traditional society associates women with giving birth, a connecting link in an unending stream of reproducing energy. In the religious views of many ethnic groups, including the Udmurt, 
at the archaic stage of development divine natural essence in female shape played an important role, for example in the form of the mother sun (Shundy-mumy), the mother moon (Tolez'mumy), mother earth (Muz"yem-mumy), etc. In this regard, the philosophical depth of a folk song with what appears at first glance to be very simple words is revealed:

Shundy no dzh'uzha no, Shundy no puks'e no.

Nosh ik so intyye

Tolez' no dzh'uzha.

Pios / nyl"yos no budo no,

Pios / nyl"yos no koshko no,

Nosh ik so intyye

Pios / nyl'yos budylo.

S'as'ka no dzh'uzha no,

S'as'ka no töldzh'e no.

Nosh ik so intyye

Yemysh bygyl'ske...
The sun and rises and,

The sun and sets and.

Instead of it

The moon rises.

Daughters/sons grow up and,

Daughters/sons go away and.

Instead of them

Daughters/sons grow up...

Flowers and bloom and,

Flowers and fall and.

Instead of them

Fruit appears...

(Authors' interlinear translation)

Overall maiden and women's festivals reflect a specific aspect of gender and age stratification of the village community as it relates to the calendar. In the rites and celebrations of the annual cycle, all members of the village community were always involved and each age and gender group was involved in the actional structure of the rites at different levels. The ratio of participants depended on the functions of each ritual and notions about the interdependence of cyclic (natural-space) and linear (personal) time (spring is youth, summer is maturity, autumn is old age, winter is death), as well as on mythological ideas about magic stimulation and the possibilities that both nature and man have for production. 


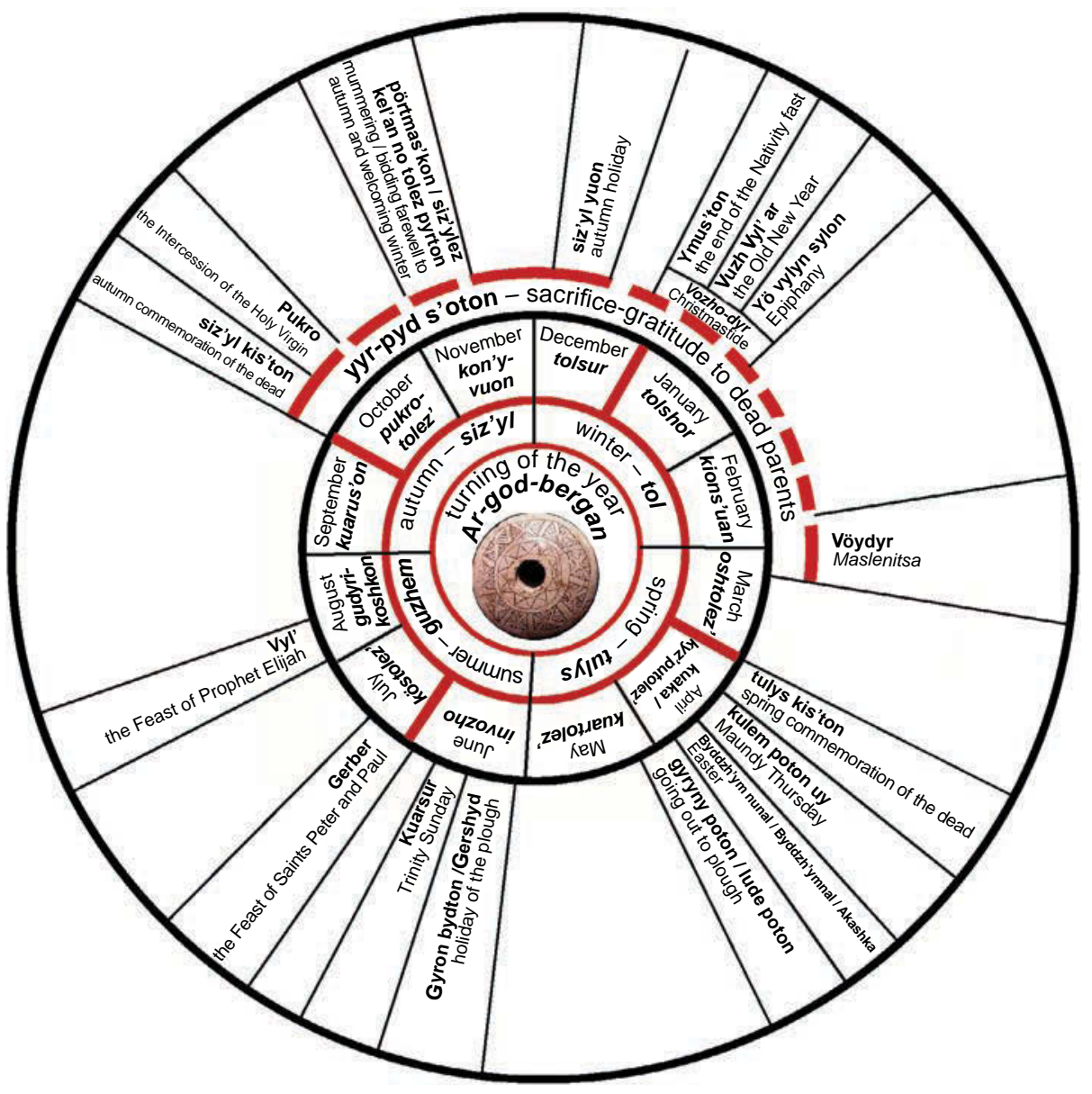

Diagram 1. Diagram of the Udmurt's ritual calendar, elaborated by Vladimir Vladykin and Tatiana Vladykina, 1990. 
Ar-god-bergan - "turning of the year" = "wheel of the year" = calendar Ar-godbergan

winter - tol

spring - tulys

summer - guzhem

autumn - siz'yl

January - tolshor / tolshor tolez' = "middle of winter"/ midwinter month

February-kions'uan/kions'uan tolez" ="wolf's wedding"/month of wolf's weddings March - oshtolez' / vutolez' / vuoshtolez' = "month of the bull" / "month of water" / "month of the waterbull"

April - kyz'putolez' $=$ month of the birch / month of the birch sap / kuakatolez' $=$ month of the rook

May - kuartolez' $=$ month of [the green] foliage

June - invozho / invozho tolez' $=$ month of invozho / month of flowers invozho / month of flowers of wild carnations / "angry" month / transition month July - köstolez' = dry month

August - gudyrikoshkon / gudyrikoshkon tolez' = leaving of the thunder / month of the leaving of the thunder

September - kuarus'on / kuarus'on tolez' = leaf fall / month of leaf fall

October - pukrotolez' $=$ month of [snow] cover / month of the Intercession of the Holy Virgin

November-kon'yvuon/kon'yvuon tolez'= month when squirrels reach maturity December - tolsur $=$ month of winter beer $/$ month of winter holiday

yyr-pyd s'oton - lit: "head-legs sacrifice/offering" = sacrifice-gratitude to dead parents

Vozho-dyr - Christmastide

Ymus'ton - lit: "opening of the mouth" = the end of the Nativity fast

Vuzh Vyl' ar - the Old New Year (New Year according to Julian Calendar on 14 January)

Yö vylyn sylon - lit: "stand in gonice" = Epiphany (celebrated on 19 January) Vöydyr - lit: "butter time" = Maslenitsa (a spring holiday celebrated a week before the Great Lent)

tulys kis'ton - lit:"spring libation" = spring commemoration of the dead kulem poton uy - lit: "night when the dead come" = Maundy Thursday Byddzh'ym nunal / Byddzh'ymnal / Akashka - Great Day - Easter gyryny poton / lude poton - lit: "going out to plough"

Gyron bydton / Gershyd - the end of sowing; lit: "soup / treat in honour of the plough" = holiday of the plough

Kuarsur - lit: "beer of leaves / greenery" = holiday of [green] foliage = Trinity Sunday

Gerber - lit: "after the plough" = the Feast of Saints Peter and Paul

Vyl' - lit: "new" = New Year = the Feast of Prophet Elijah

siz'yl kis'ton - lit: 'autumn libation' = autumn commemoration of the dead

Pukro - the Intercession of the Holy Virgin

pörtmas'kon / siz'ylez kel'an no tolez pyrton - mummering/ bidding farewell to autumn and welcoming winter

siz'yl yuon - autumn holiday 


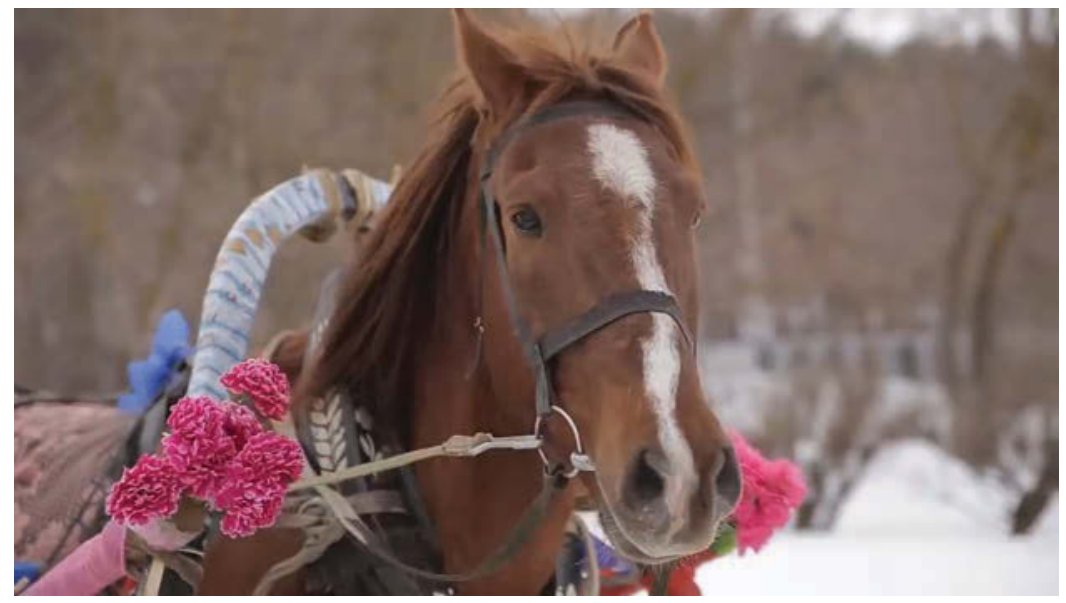

Photo 1. A horse at the ritual Seeing off of Shrovetide. Bob'ya-Ucha, Malaya Purga district, Udmurt Republic, 2016. Source: https://youtube.com/ playlist?list=PLGROZcMSNIi_BTODN, last accessed 10.6.2021.

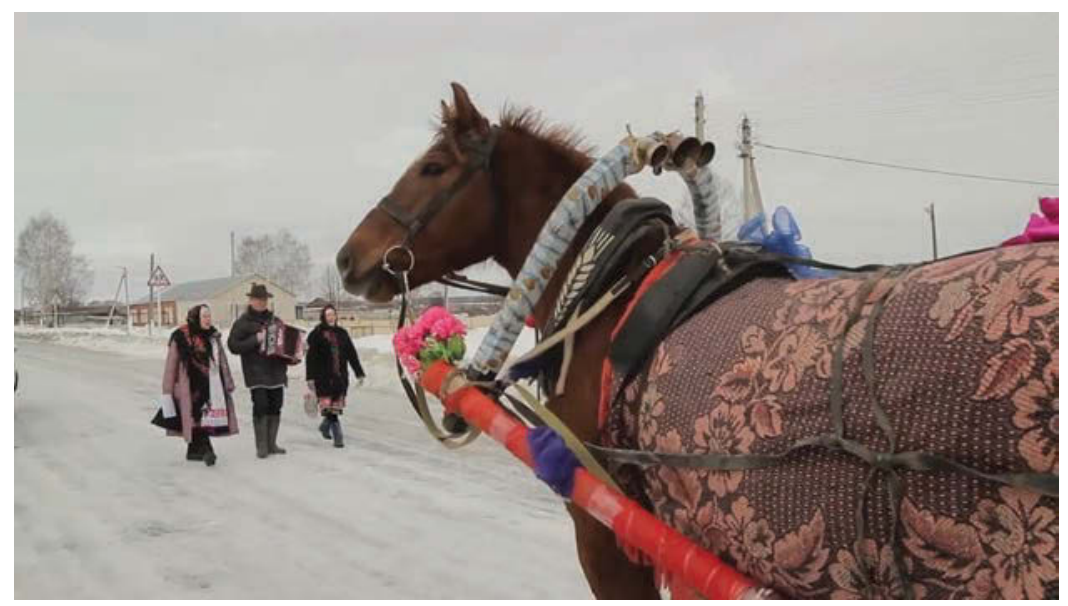

Photo 2. A horse at the ritual Seeing off of Shrovetide. Bob'ya-Ucha, Malaya Purga district, Udmurt Republic, 2016. Source: https://youtube.com/ playlist?list=PLGROZcMSNIi_BTODN, last accessed 10.6.2021. 


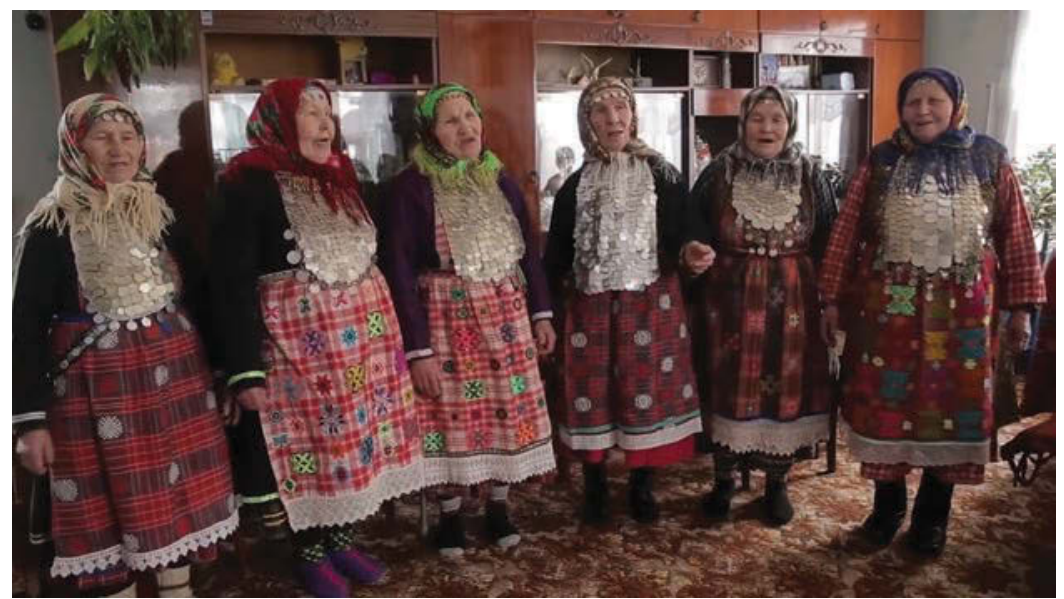

Photo 3. Singing a ritual tune. Shrovetide in Bob'ya-Ucha, Malaya Purga district, Udmurt Republic, 2016. Source: https:/youtube.com/ playlist?list=PLGROZcMSNIi_BTODN, last accessed 10.6.2021.

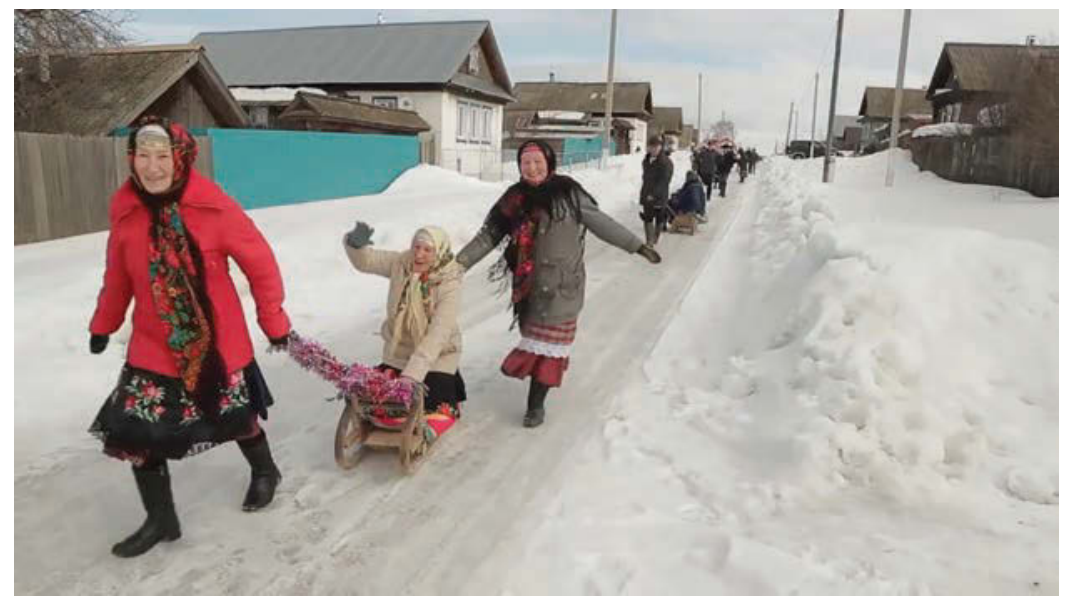

Photo 4. Women riding sledges, as incarnations of Shrovetide. Bob'ya-Ucha, Malaya Purga district, Udmurt Republic, 2016. Source: https://youtube.com/ playlist?list=PLGROZcMSNIi_BTODN, last accessed 10.6.2021. 


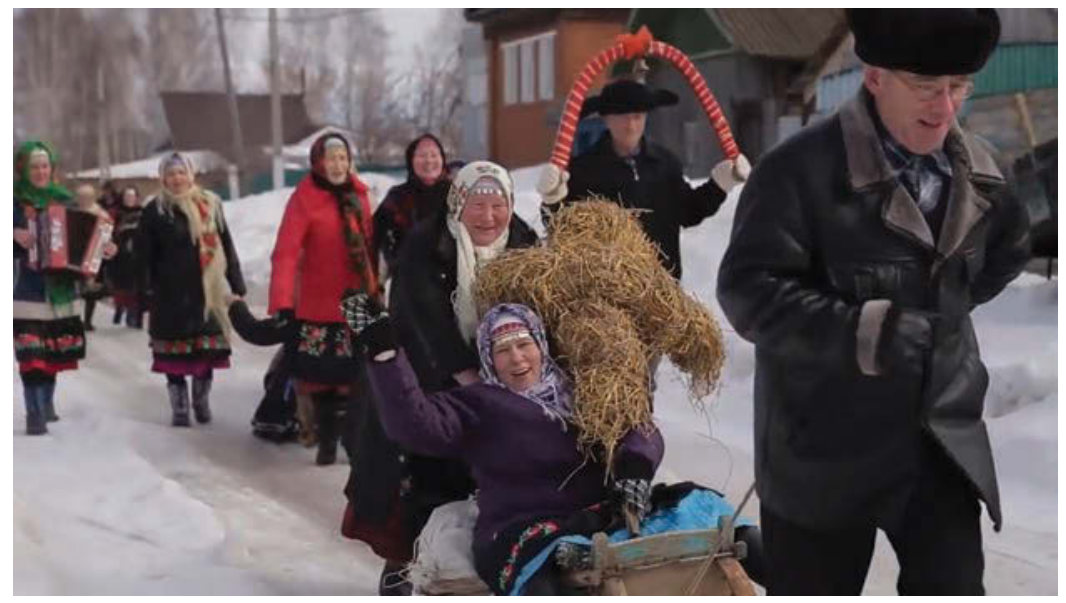

Photo 5. A dummy representing Shrovetide is led to the edge of the village to be burned. Bob'ya-Ucha, Malaya Purga district, Udmurt Republic, 2016. Source: https://youtube.com/playlist?list=PLGROZcMSNIi_BTODN, last accessed 10.6.2021.

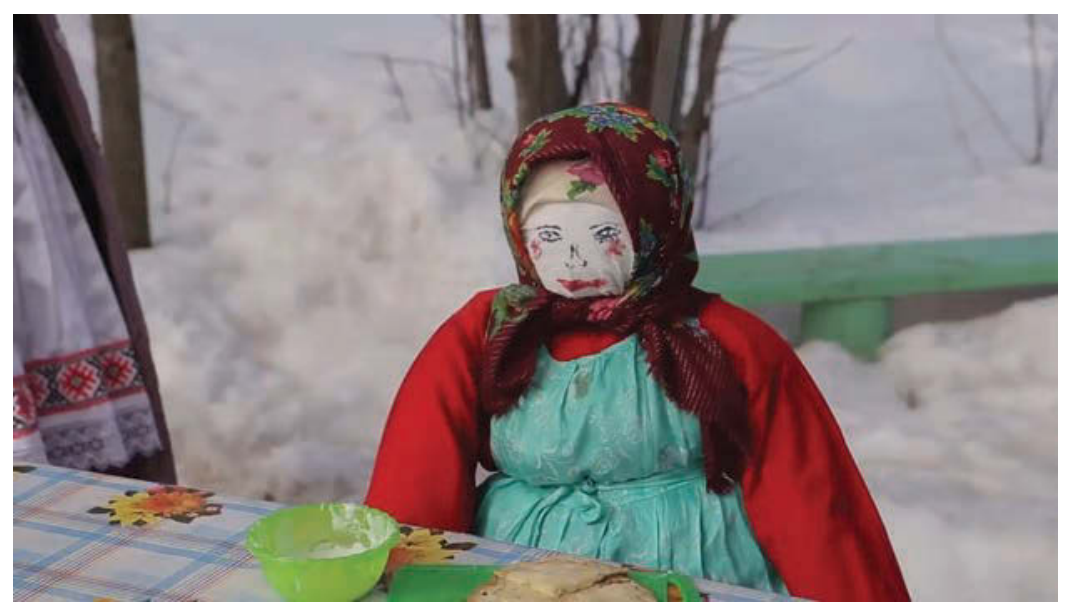

Photo 6. Food for the doll-Shrovetide. Bob'ya-Ucha, Malaya Purga district, Udmurt Republic, 2016. Source: https://youtube.com/ playlist?list=PLGROZcMSNIi_BTODN, last accessed 10.6.2021. 


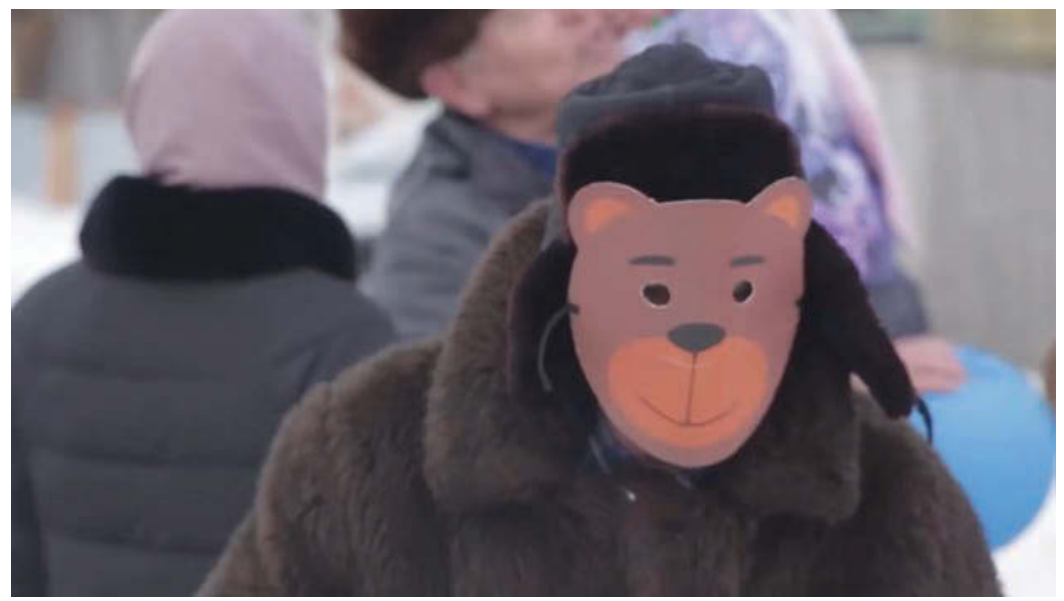

Photo 7. The "bear" at Shrovetide. Bob'ya-Ucha, Malaya Purga district, Udmurt Republic, 2016. Source: https://youtube.com/playlist?list=PLGROZcMSNIi BTODN, last accessed 10.6.2021.

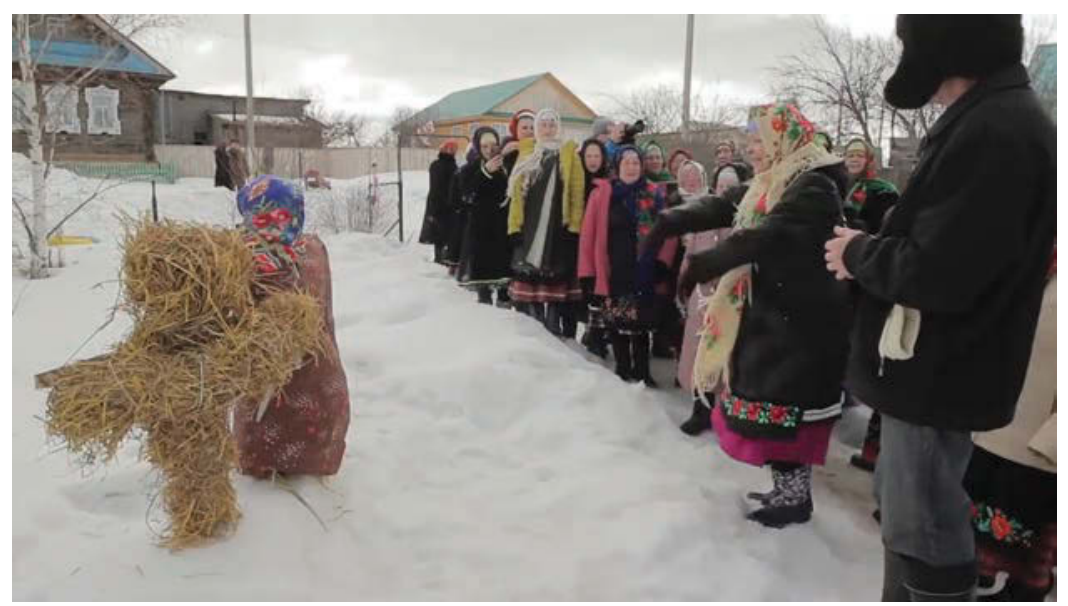

Photo 8. The dummy representing Shrovetide before the ritual burning. Bob'ya-Ucha, Malaya Purga district, Udmurt Republic, 2016. Source: https:// youtube.com/playlist?list=PLGROZcMSNIi_BTODN, last accessed 10.6.2021. 
Tatiana Vladykina, Galina Glukhova, Tatiana Panina

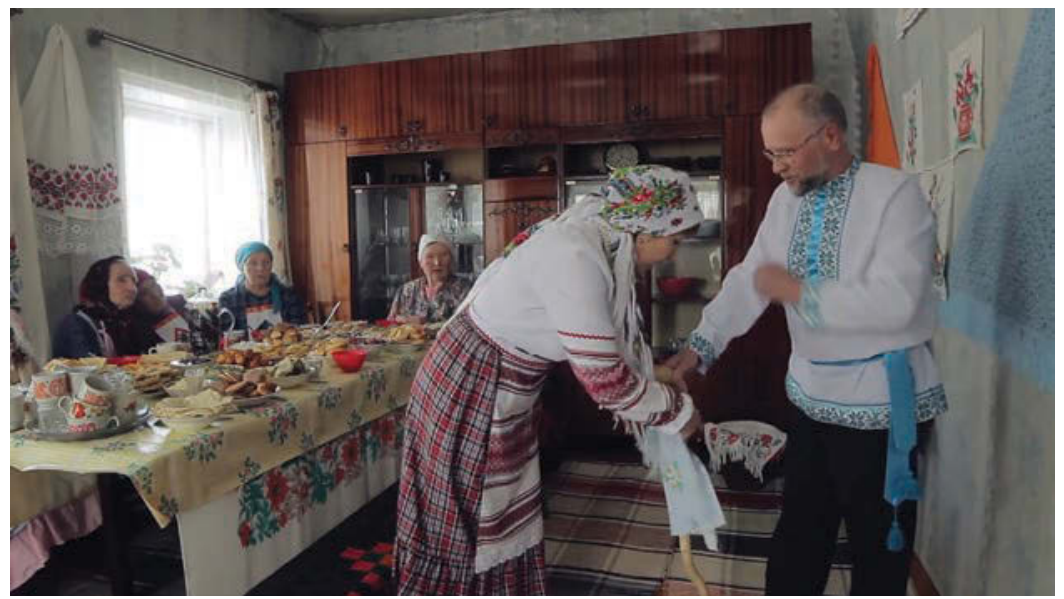

Photo 9. The wife of the man responsible for the ritual ties chuk in the form of a towel to the staff. Kel'dysh, Sharkan district, Udmurt Republic, 2016. Source: https://youtube.com/playlist?list=PLGROZcMSNIi_BTODN, last accessed 10.6.2021.

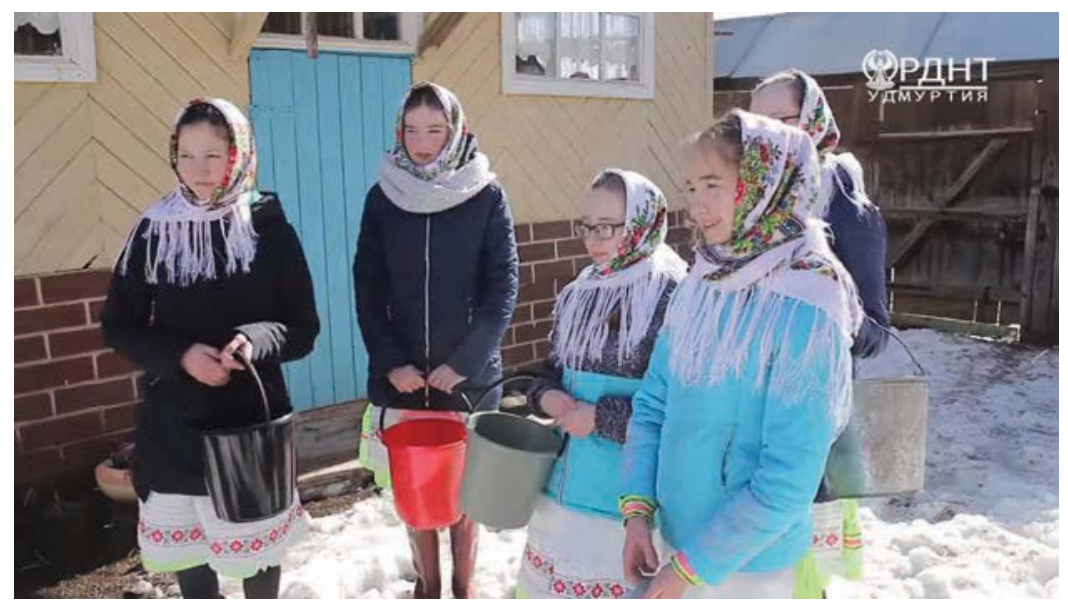

Photo 10. Collecting food for the ritual porridge. Karamas-Pel'ga, Kiyasovo district, Udmurt Republic. Source: https://youtube.com/ playlist?list=PLGROZcMSNIi_BTODN, last accessed 10.6.2021. 


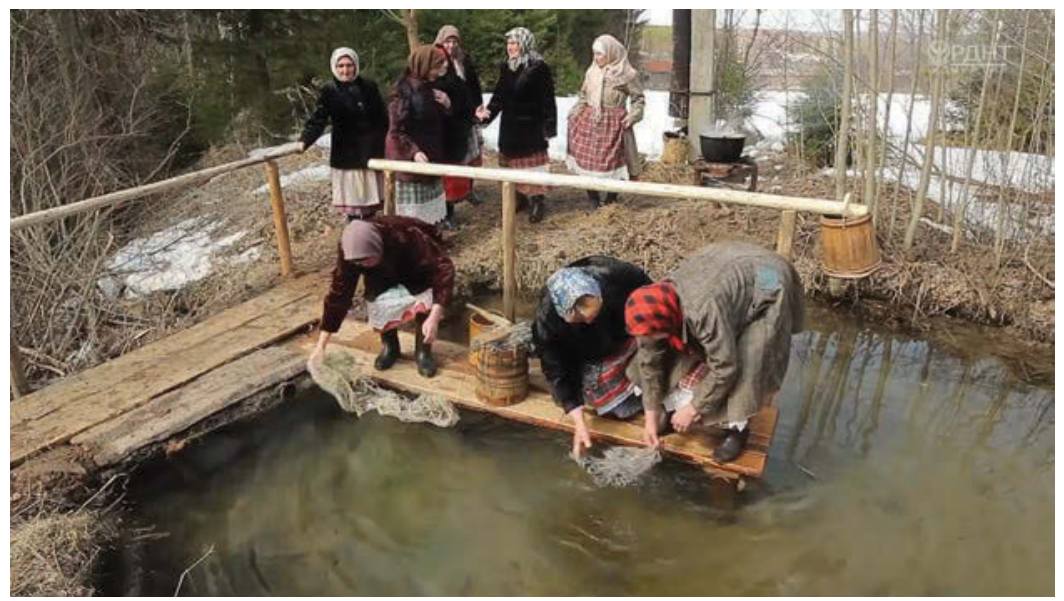

Photo 11. The washing of threads. Reconstruction of ritual. Srednyeye Shadbegovo, Igra district, Udmurt Republic, 2019. Source: https://youtube. com/playlist?list=PLGROZcMSNIi_BTODN, last accessed 10.6.2021.

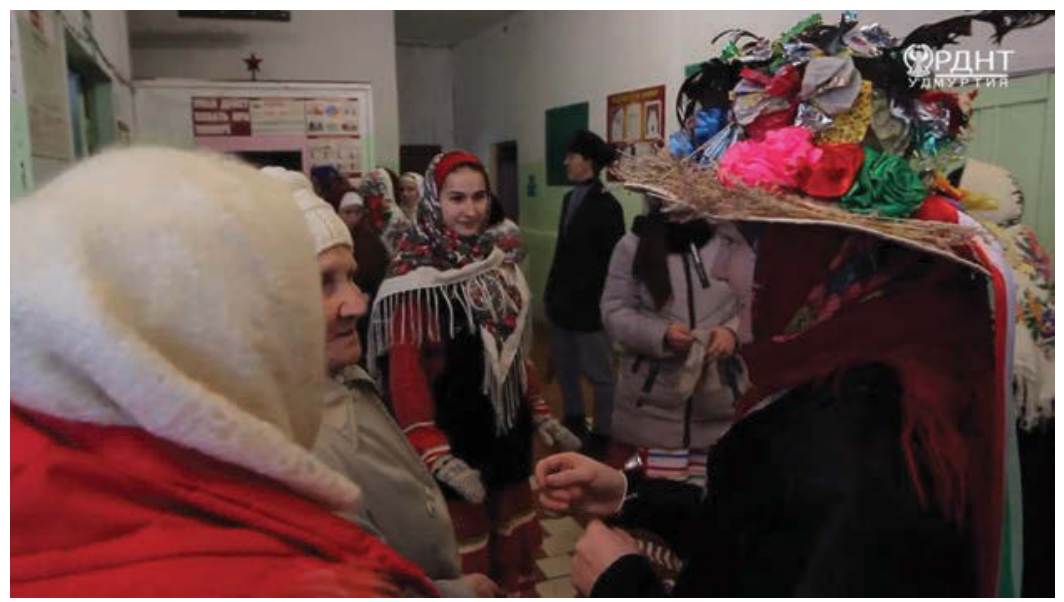

Photo 12. The ritual hat at the siz'yl pörtmas'kon autumn mumming ritual. Novaya Mon'ya, Selty district, Udmurt Republic, 2019. Source: https://youtube. com/playlist?list=PLGROZcMSNIi_BTODN, last accessed 10.6.2021. 
Tatiana Vladykina, Galina Glukhova, Tatiana Panina

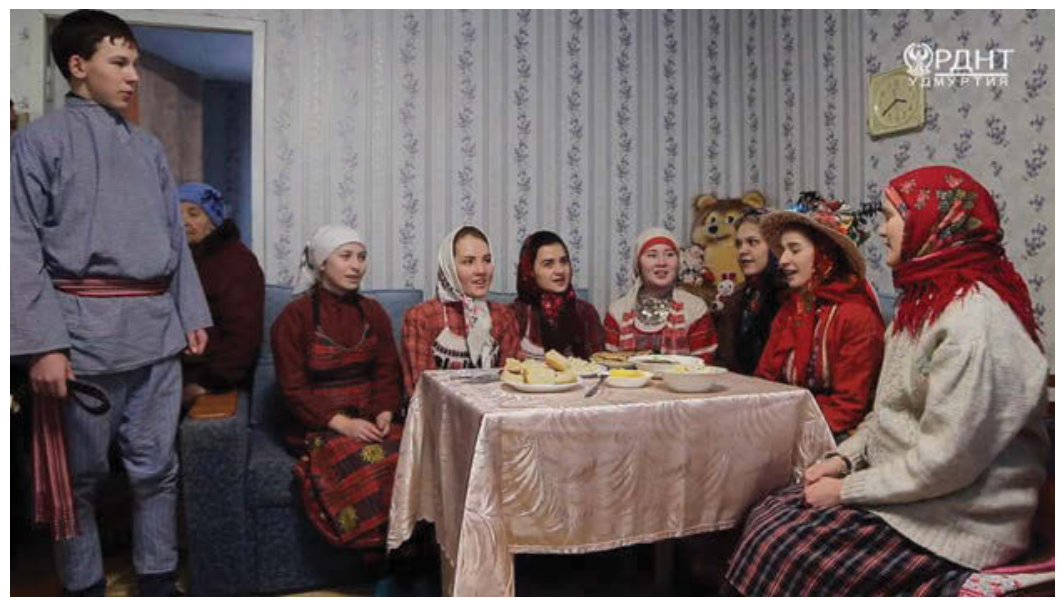

Photo 13. Traditional celebration. Novaya Mon'ya, Selty district, Udmurt Republic, 2019. Source: https://youtube.com/playlist?list=PLGROZcMSNIi BTODN, last accessed 10.6.2021.

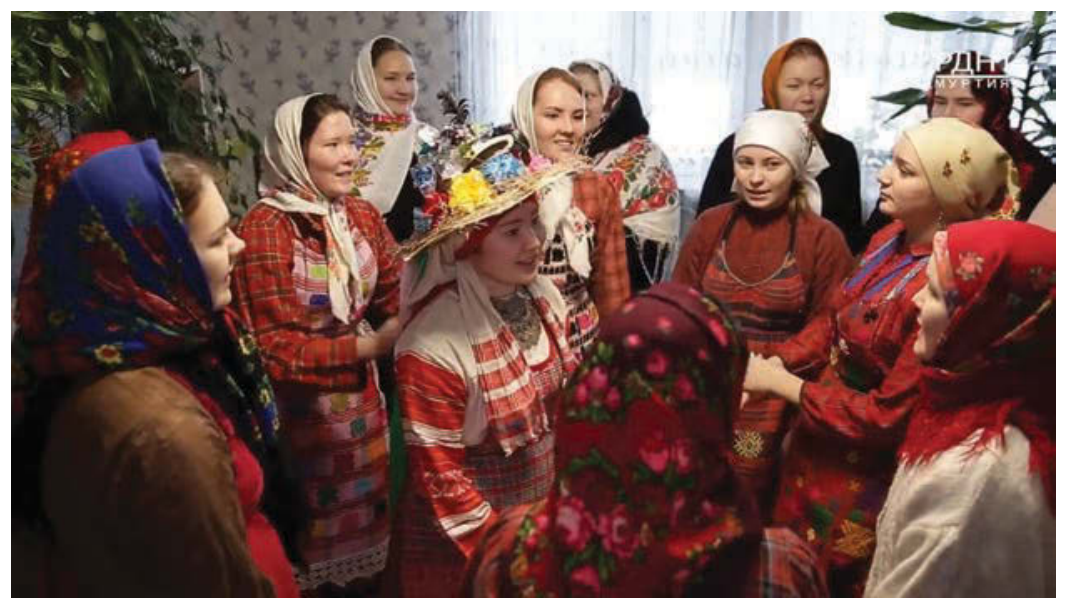

Photo 14. The ritual participants after the celebration. Novaya Mon'ya, Selty district, Udmurt Republic, 2019. Source: https://youtube.com/ playlist?list=PLGROZcMSNIi_BTODN, last accessed 10.6.2021. 


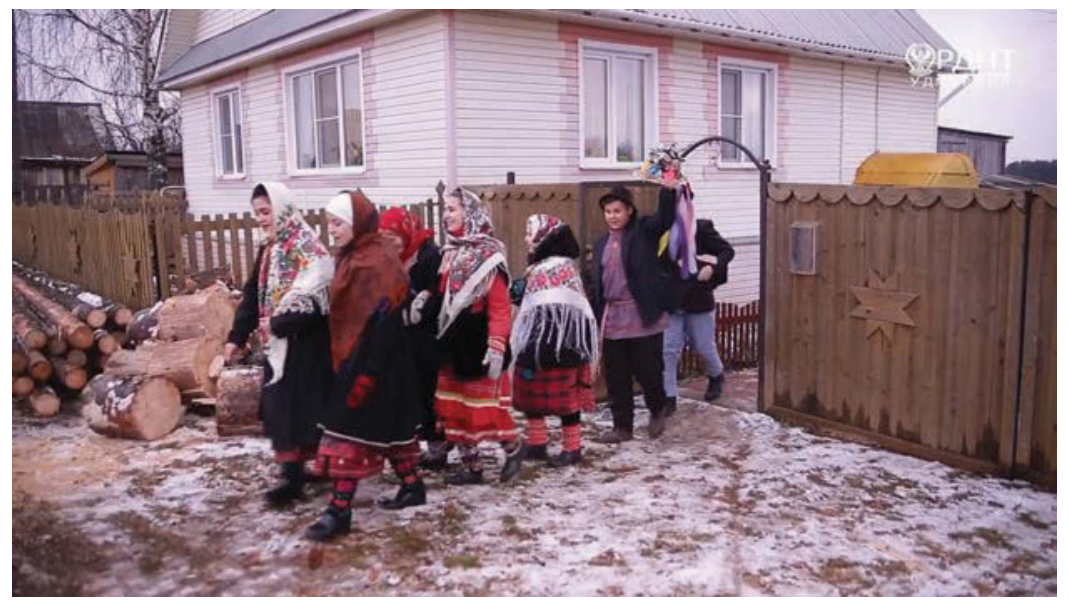

Photo 15. The ceremony of going from house to house performed by the participants in the ritual. Novaya Mon'ya, Selty district, Udmurt Republic, 2019. Source: https://youtube.com/playlist?list=PLGROZcMSNIi_BTODN, last accessed 10.6.2021.

\section{Note}

1 The article is written within the Program of Fundamental Researches of the Ural Branch of the Russian Academy of Sciences in 2015-2017 on "Udmurt Mythology in Historical and Cultural Heritage" No. 15-13-6-8.

\section{References}

Agapkina, T. 2009. Put' obryadovyy [Ritual path]. In: N. Tolstoy (ed.-inchief). Slavyanskie drevnosti: Etnolinguisticheskiy slovar v 5-ti tomakh: $P-S$. [Slavic Heritage: Ethnolinguistic Dictionary in 5 Volumes. 1: P-S.] Moscow: Mezhdunarodnye otnosheniya.

Alatyrev, V. 1988. Etimologicheskiy slovar' udmurtskogo yazyka: Bukvy $A$, B. [Etymological Dictionary of the Udmurt Language: Letters A, B.]. Izhevsk: Nauchno-issledovatel'skiy institut pri Sovete Ministrov UASSR. 
Bernshtam, T.1988. Molodezh v obryadovoy zhizni russkoy derevni XIX-nachala XX v.: Polovozrastnoy aspect traditsionnoy kultury [Young People in the Ceremonial Life of the Russian Village of the $19^{\text {th }}-$ Beginning 20 ${ }^{\text {th }}$ Century: Age and Gender Aspect of Traditional Culture]. Leningrad: Nauka.

Bushkevich, S. 2009. Kuritsa [Hen]. In: N. Tolstoy (ed.-in-chief). Slavyanskiye drevnosti: Etnolinguisticheskiy slovar'v 5-ti tomakh: $K-P$. [Slavic Heritage: Ethnolinguistic Dictionary in 5 Volumes. 1: K-P.]. Moscow: Mezhdunarodnye otnosheniya.

Churakova, R. 1999. Pesni yuzhnyh udmurtov [Songs of Southern Udmurts]. Izhevsk: Udmurtskiy institut istorii, yazyka i literatury Ural'skogo otdeleniya Rossiyskoy akademii nauk.

Dolganova, L. \& Morozov, I. 1995. Igry i razvlecheniya udmurtov: istoriya $i$ sovremennost' [Games and Entertainment of the Udmurts: History and Present Time]. Moscow: Udmurtskiy institut istorii, yazyka i literatury Ural'skogo otdeleniya Rossiyskoy akademii nauk.

Kabakova, G. 1999. Zhenshchina [Woman]. In: N. Tolstoy (ed.-in-chief). Slavyanskiye drevnosti: Etnolingvisticheskiy slovar v 5-ti tomakh: $D-K$. [Slavic Heritage: Ethnolinguistic Dictionary in 5 Volumes. 2: D-K.] Moscow: Institut slavyanovedeniya RAN.

Khristolyubova, L. 1995. Kalyk s'am"yosty chaklasa [Following Folk Traditions]. Izhevsk: Udmurtia.

Lytkin, V., Gulyaev, E. 1970. Kratkiy etimologicheskiy slovar komi yazyka [Short Etymological Dictionary of the Komi Language]. Syktyvkar: Nauka.

Minniyakhmetova, T. 2000. Kalendarnyye obryady zakamskikh udmurtov [Calendar Rites of the Eastern Udmurts]. Izhevsk: Udmurtskiy institut istorii, yazyka i literatury Ural'skogo otdeleniya Rossiiskoy akademii nauk.

Morozov, I. 1998. Zhenit'ba dobra molodtsa: Proiskhozhdeniye $i$ tipologiya traditsionnyh molodezhnykh razvlecheniy s simvolikoy 'svad'by'/'zhenit'by' [Marrying of a Fine Young Man: Origin and Typology of Traditional Youth Holidays with 'Wedding' Symbolic]. Moscow: Gosudarstvennyy respublikanskiy tsentr russkogo fol'klora; Izdatel'stvo "Labirint". 
Munkácsi, B. 1952. Volksbräuche und Volksdichtung der Wotjaken [Folk Customs and Folk Poetry of the Votyak]. Aus dem Nachlasse von Bernhard Munkácsi. Herausgegeben von D. R. Fuchs. MSFOu, 102. Helsinki SUS.

Nuriyeva, I. 1999. Muzyka v obryadovoy kul'ture zavyatskih udmurtov: Problemy kul'turnogo konteksta i traditsionnogo myshleniya [Music in Ceremonial Culture of the Trans-Vyatka Udmurts: Problems of Cultural Context and Traditional Way of Thinking]. Izhevsk: Udmurtskiy institut istorii, yazyka i literatury Ural'skogo otdeleniya Rossiyskoy akademii nauk.

Pervukhin, N. 1888 (2). Eskizy predaniy $i$ byta inorodtsev Glazovskogo uyezda [Essays about the Legends and the Everyday Life of Non-Russians of the Glazov District]. Eskiz 2: Idolozhertvennyy ritual drevnikh votyakov po ego sledam $\mathrm{v}$ rasskazakh starikov i v sovremennykh obryadakh [Essay 2: The Idol-Sacrificial Ritual of the Ancient Votyak in Its Traces in the Stories of Elder People and in Modern Rituals]. Vyatka: Gubernskaya tipografiya.

Stepanova, A. 1985. Metaforicheskiy mir karel'skikh prichitaniy [The Metaphorical World of the Karelian Lamentations]. Leningrad: Nauka.

Tolstaya, S. 1996. Simvolika devstvennosti v Polesskom svadebnom obryade [Symbolic of Virginity in Polessky Wedding Ritual]. In: Seks $i$ erotica $v$ traditsionnoy russkoy kul'ture [Sex and Erotic in the Traditional Russian Culture]. Moscow: Ladomir, pp. 192-206.

Vasil'yev, I. 1906. Obozreniye yazycheskikh obryadov i verovaniy votyakov Kazanskoy, Vyatskoy guberniy [An Overview of Pagan Rituals and Beliefs of the Votyaks in the Kazan and Vyatka Governorates]. Izvestiya Obshchestva arkheologii, istorii i etnografii pri Imperatorskom Kazanskom universitete 5. [Journal of the Society of Archaeology, History and Ethnography at the Imperial Kazan University]. Kazan: Kazanskaya tipo-litografiya Imperatorskogo universiteta, pp. 321-349.

Vereshchagin, G. 1996. Votyaki Sarapul'skogo uyezda Vyatskoy gubernii. Sobranie sochineniy v $6 t$. [The Votyaks of Sarapul District, Vyatka Governorate. Collected Works in 6 Volumes]. II. Izhevsk: Udmurtskiy institut istorii, yazyka i literatury Uralskogo otdeleniya Rossiyskoy akademii nauk. 
Vinokurova, I. 1994. Kalendarnyye obychai, obryady i prazdniki vepsov (konets XIX-nachalo XX v.) [Calendar Customs, Rituals and Celebrations of the Vepsians (End 19 ${ }^{\text {th }}-$ Beginning 20 ${ }^{\text {th }}$ Century)]. SanktPetersburg: Nauka.

Vladykina, T. 2006. Atributivnye i verbal'nye paralleli v udmurtskom i russkom svadebnom ritualakh [Attributive and Verbal Parallels in Udmurt and Russian Wedding Rituals]. In: V. Gatsak \& T. Vladykina (eds.) Russkiy Sever i vostochnye finno-ugry: problemy prostranstvennovremennogo fol'klornogo dialoga. Materialy I Mezhregional'noy konferentsii $i$ VII Mezhdunarodnoy shkoly molodogo fol'klorista. Izhevsk, 23-26 oktyabrya 2005 g. [Northern Russia and Eastern FinnoUgrians: Problems Concerning Time and Space in Folk Dialogue. Materials of the $1^{\text {st }}$ Inter-regional Conference and $7^{\text {th }}$ International School for Young Folklorists. Izhevsk, 23-26 October 2005]. Izhevsk: ANK, pp. 50-57.

Vladykina, T. 2012. Vsego ob odnoy pesennoy formule osennego ryazhenya udmurtov-kalmezov [Just about One Song Formula of Autumn Disguise of the Udmurt-Kalmez]. In: Problemy kul'turno-yazykovoy regionalistiki [Problems of Cultural-Linguistic Regional Studies]. Perm', pp. 190-194.

Vladykina, T. 2013. Pominal'nyye obryady udmurtov: yavnoye i neochevidnoye [Funeral Rituals of the Udmurts: The Obvious and the NonObvious]. In: Narodnaya kul'tura $v$ slove i tekste: sb. issl-y i materialov pamyati Valentiny Viktorovny Filippovoy [Folk Culture in Word and Text: Collection of Research Works and Materials in Memory of Valentina Viktorovna Filippova]. Syktyvkar: Izd-vo SyktGU, pp. 32-37.

Vladykina, T., Glukhova, G. 2011a. Dni nedeli v systeme predstavleniy udmurtov o vremeni [Days of week in the system of views on time of the Udmurts]. Yezhegodnik finno-ugorskikh issledovaniy. Issue 3, pp. $38-54$.

Vladykina, T., Glukhova, G. 2011b. Ar-god-bergan: Obryady i prazdniki udmurtskogo kalendarya [Year-Circle: Rituals and Celebrations of the Udmurt Calendar]. Izhevsk: Udmurtskiy universitet.

Vladykina, T., Glukhova, G. 2013. Etnokulturnyy kontekt predstavleniy udmurtov o vremeni [Ethno-Cultural Context of Views on Time of the Udmurts]. Traditsionnaya kul'tura, Vol. 1, pp. 111-117. 


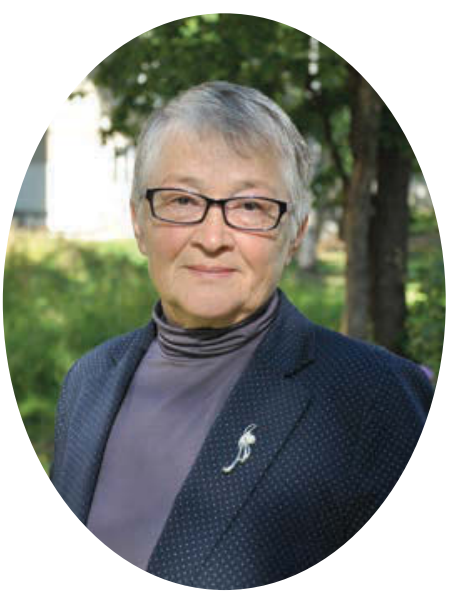

Tatiana Vladykina is ( $\mathrm{PhD}$ hab) a professor and leading researcher at the Udmurt Institute for Research in History, Language and Literature (Udmurt Federal Research Centre of the Ural Branch of the Russian Academy of Sciences). She has covered the range of topics in Udmurt folkloristics, especially mythology, specialising both in genre and in the treatment of the most important topics across genres.

e-mail: tgvladykina@mail.ru

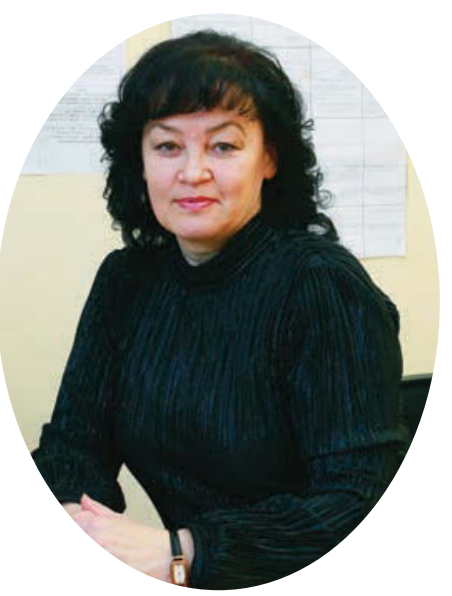

Galina Glukhova ( $\mathrm{PhD}$ ) is an associate professor and director of the Institute of Udmurt Philology, Finno-Ugric Studies and Journalism of Udmurt State University and teaches Udmurt literature and folklore. Her main field of interest is related to research on Udmurt and FinnoUgric folklore, Udmurt traditional culture, and the interaction of Udmurt folklore and literature. e-mail: galant@udm.ru 


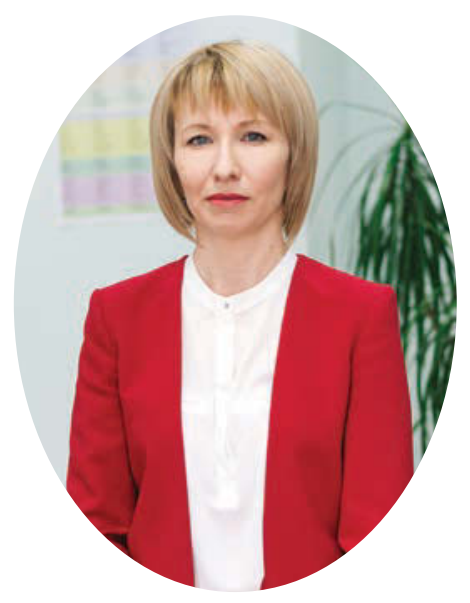

Tatiana Panina (PhD) is a researcher at the Department of Philological Studies, at the Udmurt Institute for Research in History, Language and Literature (Udmurt Federal Research Centre of the Ural Branch of the Russian Academy of Sciences). She is interested in traditional Udmurt culture, more precisely in folk medicine, incantation tradition and more recently dreams. Panina teaches English at the Izhevsk State Medical Academy. e-mail: tipanina@mail.ru 